\title{
The Many Faces of Displacement. Pervasive Violence and the Dissolution of a Liveable Life in IraQ, Syria and Afghanistan
}

\author{
Andreas HACKL, University of Edinburgh, Social Anthropology
}

\section{Content}

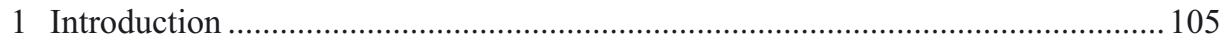

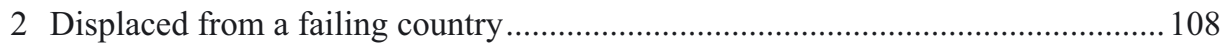

3 From sectarianism to pervasive violence …………………………………..... 110

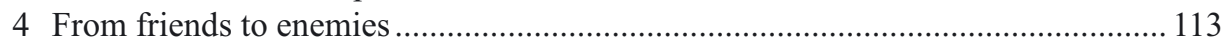

5 Syria: political displacement and immobility in a protracted crisis ........................ 117

6 Afghanistan: displaced women, "infidels" and forced returnees ............................. 120

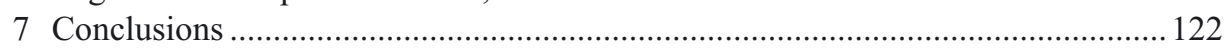

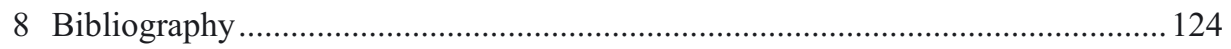

\section{Introduction}

From Iraq to Afghanistan and Syria, war and violent conflict remain the main reasons behind the continuing prevalence of forced displacement and flight around the world. What current research tends to neglect is the pervasive impact these violent upheavals have on all layers of human life, by weakening the social fabric, undermining economic wellbeing and creating a climate of fear and mistrust. This chapter analyses several intersecting push-factors behind displacement and flight with a focus on Iraq, complemented by insights on Syria and Afghanistan. One goal is to challenge the myth that the reasons behind people's flight from their home country can be isolated and simplified. What the popular debates surrounding displacement and forced migration 
continuously overlook are the tremendous long-term effects of protracted conflict and violence and the many ways in which these effects extend into all aspects of daily life, pushing people out of their homeland as their lives become unliveable.

Being confronted with the option of flight from one's home country is no longer an exception but rather a widespread aspect of the human condition. It is a truly global phenomenon as one in four people on the planet live in fragile and conflict-affected states, conflicts that tend to repeat themselves: 90 percent of civil wars in the early 2000s occurred in countries that had already had a civil war in the previous 30 years (WoRLD BANK 2011, p. 3). If conflicts are enduring and recurring, their violence can no longer be disconnected from poverty and stagnating economic and institutional development: factors that make displacement all the more likely. Countries that experienced major violence from 1981 to 2005 had an average poverty rate 21 percentage points higher than that of countries that saw no violence (Ibid, p. 5). The violent conflicts over Syria, Iraq and Afghanistan led to widespread insecurity, mistrust and the breakdown of institutions, which are all considered vital for breaking the mutually reinforcing cycles of violence, poverty and state fragility. Whether for those who leave or those who are left behind: the human and socio-economic costs of violence for citizens, communities, countries, and the world more generally have grown to enormous proportions. Often lacking the resources to begin a new life elsewhere, vulnerable groups in society are most affected by violent conflict:

Violence destroys school infrastructure, displaces teachers, and interrupts schooling, often for an entire generation of poor children. War, looting, and crime destroy the household assets of the poor, and fear of violent attacks prevents them from tilling their fields or travelling to schools, clinics, workplaces, and markets. (WORLD BANK 2011, p. 59)

In a similar vein, "Iraqi society has been transformed by violence and the pervasiveness of deep mistrust amongst its population" (SAsson 2010, p. 4). The fragile ties that held society together unravel with the explosion of violence and its many social consequences. What pushes most people into exile is then not simply violence or persecution, it is violence coupled with state "dysfunctionality" and socio-economic problems: the various challenges facing fragile states interact together to influence the chances of stability, development and peace (RossiER 2011).

However, in the strict legal sense a refugee is an individual who, "owing to wellfounded fear of being persecuted for reasons of race, religion, nationality, membership of a particular social group or political opinion, is outside the country of his nationality." The groups and individuals facing an unstable and increasingly dangerous situation of pervasive violence and insecurity might then not be considered legitimate refugees under certain circumstances. The conventions are important pillars of international human rights and their narrow definition is aimed at protecting the most vulnerable. It is nevertheless important to complement this perspective with the continuing critical examination of

Article 1A (2) of the 1951 Convention Relating to the Status of Refugees. 
the multi-layered developments that push people to the point of flight in the absence of any viable alternative. While the UN Refugee Agency (UNHCR) provides assistance and protection for refugees throughout the world, the 1951 Convention relating to the Status of Refugees remains the cornerstone of that protection. However, "millions more people have fled their countries for reasons that the drafters of the Convention could not have predicted," as a 2012 article by the humanitarian news agency IRIN suggests under the title, "Has the Refugee Convention outlived its usefulness?"2 From climate change to endemic food insecurity and generalised violence or terrorism: the context is widely believed to have changed.

We will see that the eventual decision to flee often emerges from a combination of multiple related forces and developments, many of them with strong repercussions within immediate social and familial circles. Although often forced in one way or another, displacement nevertheless involves decisions in the face of lacking alternatives, as is evident in the words of a 35 year-old Iraqi in Austria (I1):

"My whole life, my job and family were in Iraq. I had a good job. My life was ok. Why should I have come to Europe? But sometimes life forces you to do things you don't want to do. You reach a point from which it simply cannot go on. And yes, I have reached this point and was forced to leave my country."

Many pathways lead to this point of departure. Most refugees and asylum seekers interviewed for this research experienced threats, kidnappings or had a well-founded fear of persecution and death. Some reach a "turning point" out of fear that they might be kidnapped, hurt or killed, while others might seek to break from their home country and its enduring deprivation for more complex reasons (OtTERman and Hil 2010, p. 58). These reasons are often accompanied by the shattering of realistic hopes that things might change for the better in the near future. The following discussion is based on interviews with Iraqi asylum seekers and refugees in the Austrian capital Vienna, and complemented by insights from similar interviews with Syrians and Afghans. It seeks to retrieve the lost context of multi-layered and complex displacement and position it against the increasingly one-dimensional categorisation of refugees in host countries like Austria and elsewhere around the world. The so-called "refugee crisis" does not take place in Europe, the United States or Australia. It takes place in Iraq, Syria and Afghanistan.

This argument is timely as receiving nation states and many of their citizens evaluate displacement not primarily in humanitarian terms and by drawing on knowledge about these crises, but rather as a matter of security and cultural integration based on attachment to territory. This tendency puts mounting pressure on the category of "refugee" to include an ever smaller amount of people and exclude as many as possible. This process has been underway for several years and is expected to lead to a gradual "redefinition

\footnotetext{
2 See URL: http://www.irinnews.org/analysis/2012/03/26/has-refugee-convention-outlivedits-usefulness
} 
of the term in a way that diminishes the rights to asylum, protection and assistance," meaning that fewer and fewer people will be able to claim refugee status in the future (Ретеeт 2007, p. 9). While human rights activists could possibly argue that the Refugee Convention's scope is too narrow, most governments will be quick to respond that its provisions are in fact too broad and that asylum seekers who enter a country "illegally" must be punished or sent away. In the face of the growing gap between these morally charged positions and the many faces of displacement as an experienced condition, there is an urgent need to revisit the multidimensional reality of displacement and flight against the many assumptions and qualities ascribed to the refugee. Similar to other key figures of mobility (SALAZAR 2017), such as the migrant and the exile, the refugee has become a problematic "concept-metaphor" with shifting meanings and a tension between universal claims and very particular contexts (MOORE 2004, p. 74). The argument presented builds on important critical perspectives that have discussed the scholarly objectification of the refugee and the simplification of displacement as an experienced condition (ZolberG, Suhrke, and Aguayo 1989; Malkki 1995; Peteet 2007).

\section{Displaced from a failing country}

Iraq is an ethnically and culturally diverse state with an estimated population of around 33 million, of which about 66 percent live in cities; alongside 15-20 percent Kurds and 75-80 percent Arabs some 5-10 percent of the population belongs to ethnic and cultural minorities such as Turkmens and Assyrians (ABID 2015, 11-12). At the same time, Iraq is a fragile state, imploding under the pressures of pervasive violence, recurring warfare and widespread displacement. When a fragile state such as Iraq loses the instruments of coercion and protection it also loses physical control over territory and the allegiance of the population (ALI 2013; KALDOR 2012). Militias and paramilitary groups in Iraq flourished in the absence of legitimate state authority, giving rise to "a disintegrative cycle" that further weakened the state in relation to private military groups; "their activities transformed the spaces in people's daily lives in threatening ways, prompting decisions to leave" (ALI 2013, 58). As of 2016, there were some 277,700 registered Iraqi refugees in the world (UNHCR 2016a), a much lower number than Syria (4.9 million), Afghanistan (2.7 million) and Somalia (1.1 million), which together account for more than half of the world's refugees. Signifying the extent of its internal turmoil, Iraq is the state with the most internally displaced persons worldwide, numbering about 4.4 million by 2016 (UNHCR 2016b).

Violence and displacement are certainly not new phenomena in a country that has witnessed violent upheavals long before Saddam Hussein came to power, although his reign made violence an integral part of the state. The toppling of Saddam Hussein ended 35 years of dictatorship and 12 years of harsh international sanctions against 
Iraqis. But the 2003 US-invasion led to the carnage known as "the new crisis in the Middle East", by the end of the first decade of the $21^{\text {st }}$ century (SASSON 2010). In 2007 the UN-High Commissioner for Refugees still called the Iraqi exodus the world's largest human displacement since the Palestinian exile of 1948 (Mokbel 2007). Although this exodus has been overshadowed by the Syrian and Afghan displacement, Europe has increasingly become the destination. Hundreds of thousands of Iraqis fled in response to the 1991 Gulf War, the US invasion, and from sectarian violence between 2006 and 2007, many more than the 100-120,000 Iraqis who reached Europe in 2015. And yet these earlier refugees largely sought refuge in the neighbouring Arab states of Syria and Jordan (IOM 2016, p. 11).

For a long time Iraqis were pushed outside of the international community's refugee definitions (Peteet 2007, p. 4). Only Sweden accepted large numbers of Iraqi refugees during the last decade while neither the US nor the UK admitted that there was a refugee crisis, essentially "because doing so would have meant admitting the failure of their venture in Iraq, and neither has accepted many refugees into their countries" (SASSON 2010, p. 168). Nevertheless, the current wave of Iraqi refugees followed their Syrian neighbours on the trail towards Europe. Their overly positive image of Europe when they depart does not usually match the dismal reality they eventually encounter, which is why many surrender after rejected asylum application or "endless delays of the asylum process" in Europe (IOM 2016, p. 16). The push-factors that drive them are diverse and not as clear-cut as narrow interpretations of refugee status would presume, according to the International Organization for Migration, referring to Iraq:

"Security and economic factors could not be considered as mutually exclusive, as both were periodically quoted as interlinked issues that prompted participants to decide to migrate, independently from the composition of the group. A crosscutting lack of hope that the current living conditions can change, whether on the short or long term, can be observed." (IOM 2016, p. 2)

Socio-economic problems are intertwined with the more obvious drivers of displacement in Iraq, such as threats to life and health emerging from general insecurity, arbitrary detentions and poor service provisions, alongside a lack of protection by the state; and as a consequence, "life becomes unbearably difficult and dangerous in such environments, resulting in decisions to leave" (Ali 2013, 58). Against this backdrop, many young Iraqis reach a tipping point where their decision is reduced to a choice between two equally dangerous options: fight or flight. At least this is what the International Crisis Group suggests in a report, noting that Iraqis who grew up around the upheaval of the 2003 invasion form today's "wearied" generation (al-jil al-taabaan). A local NGO leader is quoted in the report as saying: "The state has unravelled, the family structure is crumbling, and these young people cannot find work. They have come into a world that offers them no points of reference," and this "degeneration" has grown from the "cumulative impact of decades of state decline and decay" (ICG 2016). 
An important aspect of this "degeneration" is a crumbling social fabric and family structure, as individual and family life is affected by violence, corruption and the dissolution of trust within society. The risks and uncertainties people are exposed to in extreme violent settings influence people's social relationships and their understanding of trust. This familial and immediate social dimension is related to the surrounding culture of fear, clientilism and corruption in the bureaucracy. As the younger generation leaves school for jobs as day labourers, junior doctors and aspiring engineers are faced with the decision to either participate in relations of clientilism, join an armed group, or leave the country (ICG 2016, p. 9). The problem is compounded by the fact that the Iraqi government, in 2016, lacked control of many territories and neighbourhoods, which forced engineers, doctors and other professionals to rely on militias for protection. In turn, militias and the group "Islamic State" (IS) had to rely on the skills of these professionals and for that reason, tried to recruit them with violent means. Students and graduates realised that leaving the country is their only choice to break out of this vicious circle, which was one reason why many Iraqis followed their Syrian neighbours on the path to Europe by 2016 (ICG 2016, pp. 23-24).

Many Iraqis interviewed for this study have lost any hope for change. According to the 35 year-old Iraqi man I1, "the situation in Iraq will not improve, not even in a hundred years. It will take several generations." Another Iraqi man from the Al-Anbar region (I6) said that "nothing will change: On one side you have Daesh [IS], on the other all kinds of different militias; it is just a huge mess of numerous political forces and no one knows what is going on." Asked whether things might get better any time soon, another refugee from Iraq (I18) answered: "No, not in the next 100-200 years. It's going to need a miracle." Whatever may be the precise outcomes of the developments in Iraq at the time of writing: many perceived violence not as a temporary flare-up, but as a form of possible lifelong conflict. At the same time, many looked back at an equally lifelong history of war and violence. As the 24 year-old Yazidi man I2 said: "Since birth my life, and not only my personal life but that of every Iraqi, is characterised by war, oppression and threats from the state, from militias, discrimination, violence and death." The question is what does it mean for our understanding of refugee crises when whole generations, whole countries implode into a desolate state that is perceived by many as enduring, a form of permanent suffering under the impact of recurring war, violence and state failure.

\section{From sectarianism to pervasive violence}

The experience of direct violence is common among Iraqi refugees despite the many overlapping reasons that influence their decisions to leave. When the state is fragile and its monopoly of power eroded, the potential for violence seems to be constantly on the horizon. Not being directly persecuted or attacked does then not 
preclude experiencing the effects of violence and conflict, which become dispersed and infiltrate different aspects of everyday life. If multiple armed actors are geographically dispersed, violence becomes less predictable and more pervasive, especially if public security is no longer functional. One example is that of the 'Mehdi Army' militia infiltrating the newly formed Iraqi police after the US invasion of 2003, forcing

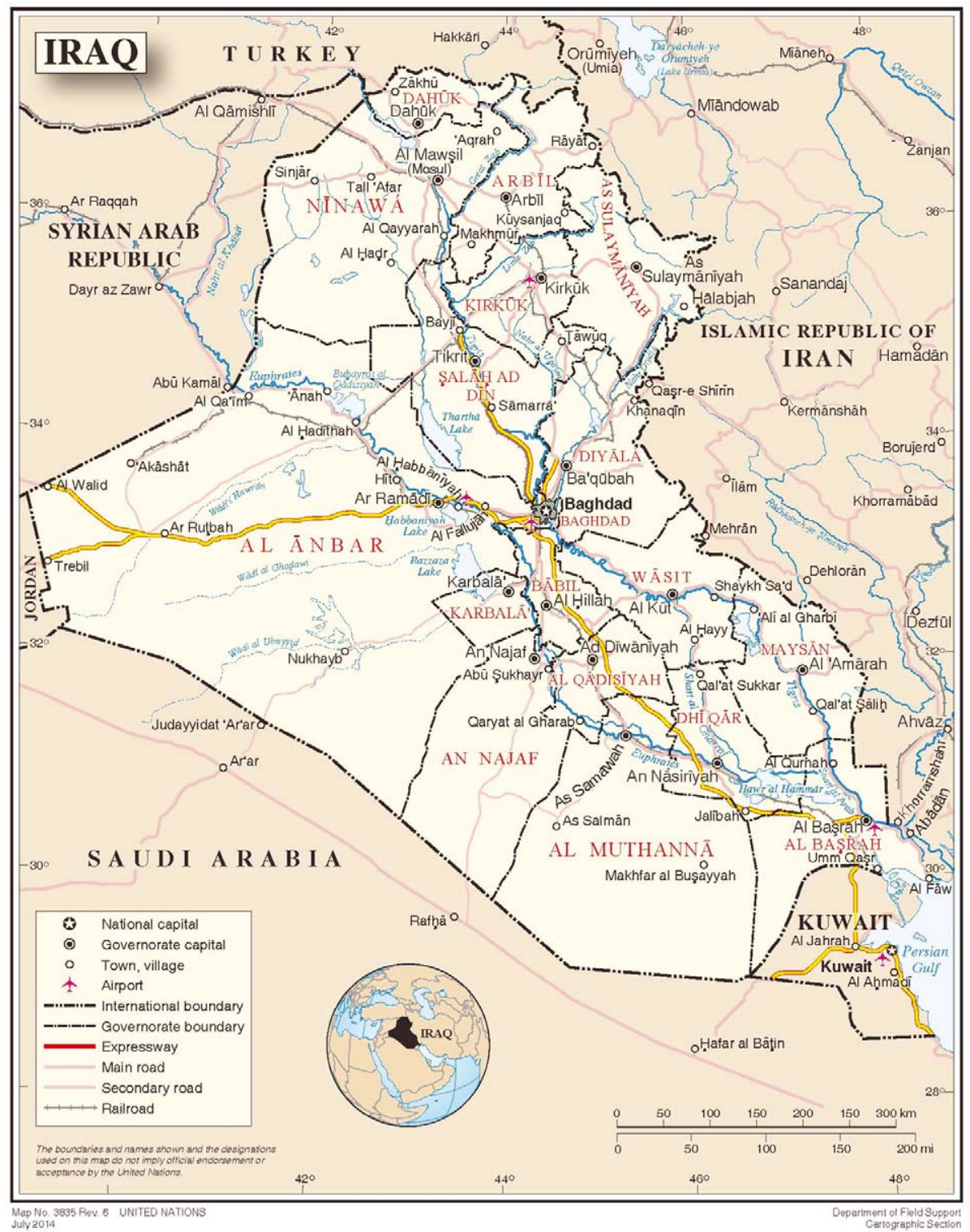


Baghdadis from their residences with the threat of violence, but also housing sympathetic families displaced by opposing militias in these forcibly vacated homes; they attacked grocers and bakers to force target populations to flee to other neighbourhoods so that militia members could pillage their homes and repopulate areas with people loyal to them: "these were manifestations of the fragility of the state in Iraqis' daily lives. They threatened human security and prompted displacement” (ALi 2013, p. 58).

The dispersion of power and violence, paired with emerging state fragility, increases the general feeling of insecurity and unpredictability in the population. In such an environment any trivial action can have serious consequences. The 22 yearold I7, a Shiite from the city of Nasiriyah at the banks of the Euphrates river, worked for a news agency "with links to political forces." When he rejected an invitation to work as a photographer for the Mehdi Army, the news agency fired him and the brigade threatened him during a series of home visits. They gave him an ultimatum of four days to change his opinion, otherwise they would "teach him a lesson," says I7. Although a Shia Iraqi himself, he faced direct threats from Shia militants who wanted to recruit him. Their involvement infiltrated aspects of ordinary life to an extent that there was no more escape, prompting a decision to leave the country. Forced displacement in this sense goes beyond simplified understandings of ethnic or religious persecution. Once violence infiltrates daily life the potentiality of death becomes an unsettling companion far beyond the boundaries of sectarian divisions.

In a similar vein, the 35 year-old Sunni Iraqi I1 came under threat while doing his job. He was responsible for clearing landmines and other obstacles at the Iraq-Iran border, so these areas could then be sold to potential buyers. Soon he was put under pressure by the Badr militia to sell the land at inflated prices and to their benefit, he explained. When he rejected their terms they threatened to kill him, which made him move away from the city into Baghdad. When they kidnapped his brother he was again pressured to leave his job in exchange for his release. He was stubborn, however, and continued to work in Baghdad after his brother's release, and so he was eventually met by gunmen who told him they knew where his family lived. He sold his house and left for Europe immediately. "It became impossible to live there, so I decided to leave the country," he said, adding that he had been to Europe seven times in the past, and ironically only a year before seeking asylum he had been to Vienna as a visitor: "My life was in order. Why should I have moved to Europe?"

When clientilism and violence penetrate daily life, one decision is often inevitable: comply, or refuse and escape? The evidently violent dynamics that prompt this decision are one example for the multi-layered pressures that force displacement. While Sunni Iraqis might be threatened by Shia militias, Shia Iraqis might be under violent pressure by Shia militias too. Simplified explanations for displacement that draw on sectarian divisions might be useful, but complex dynamics in Iraq make them largely insufficient as singular explanatory factors. 
The question of sectarianism becomes all the more complicated in the case of the 23 year-old I9, who has a Sunni mother but a Shia father. He explained that his surname clearly suggested that he was a Shiite, but said his ID card stated the Adhamiya district of Baghdad as the birthplace: a predominantly Sunni area. Amid sectarian tensions they had to leave Adhamiya and moved into a Shia district in 2010, where the whole process started from the beginning. "They pressured us to leave again because we were seen as Sunnis, so we moved again, into another Sunni district. It was a back-andforth. " In addition to leaving Adhamiya five times his brother was kidnapped twice, yet ironically: "they didn't kill him because they were not sure what he is: Sunni or Shia; they were confused and this fact might have saved his life." Although evidently driven by suggested that he was a Shiite, their case also ridicules that draw on sectarianism. The final decision to leave Iraq sprung from a different dilemma: as a journalist, he worked with a newspaper that published articles sympathetic to the government military campaigns against IS. One day he received an "illegal offer" by an armed group and tried to buy time by simply ignoring it. But after three "visits" to his office, a demolished car and threats issued against his brother, they broke into the editorial office of the paper and "smashed everything in the building." Increasingly unsafe, he convinced his mother to move and live with her sister, while he took a plane to Turkey from where he continued onwards to Austria.

\section{From friends to enemies}

Violence and displacement perpetuate one another in recurring cycles, as the departure of some creates vulnerability for others. These cycles can also affect the social fabric, for example after family members are kidnapped or threatened to leave. Emigration has an impact on those staying behind, and the circular "depletion of kinship networks" can further contribute to flight if the coping mechanisms and safety nets of the family unit are no longer in place (Ali 2013, p. 59). It follows that displacement can only be explained through a combination of factors linked to violence, which is understood as a pervasive force people must reckon with in their daily lives.

When the young Kurdish journalist I13 left the disputed city of Kirkuk towards Europe, his whole social environment had been transformed by the impact of violence and war. One might say that from his perspective, the world as he knew it had dissolved. He had lived a multicultural life in a suburb of Kirkuk where friendships between Turkmens, Arabs and Kurds were nothing unusual, but "suddenly enemies emerged from within my friendships, " he said, adding that one day he received news that an old Arab friend had moved to Mosul "to join the fight". The same friend called his house and "issued threats". Another good friend called him and said he was now fighting with IS in Mosul. When his father overheard the conversation, he quickly hung up the phone. Despite all this, unemployment is what eventually brought about his decision to leave 
after being "fed up" with this life. "What should a young person do in a country without jobs and services?" he asked, saying that he saw no more alternatives to leaving the country, and so he moved to Turkey to "wait for smugglers to get to Europe."

Most Iraqis interviewed for this research experienced direct violence or kidnappings, but the dominant explanation for why they decided to leave often referred to an overall situation that was no longer bearable. When friends turn into enemies and even one's own parents urge them to flee, staying and waiting appears no longer viable. And in some cases, such as the 26 year-old Kurdish woman I14, the decision to flee results from the rage and threats of family members rather than militias: relatives issued threats after they learned that she was meeting another man despite being married. The persecution she experienced does not qualify for refugee status, which is why she was granted subsidiary protection in Austria as she could not be safely returned to her home country. Such social and familial dynamics are not independent but deeply intertwined with the context of violence, insecurity and a lack of perspectives for a better future.

The impact that violence has on personal lives and displacement is strongly influenced by gender dynamics, which shape how households, kinship, and social networks cope with violence or generate it (see MAHLER and PESSAR 2006). The political and the domestic are interlocked in daily life, and violence as both actuality and potentiality is a force that "inheres in everyday life and constitutes a flight from it" (DAS 2008, pp. 284-285). Violence has the potential to disrupt the ordinary and it can become part of the ordinary, it can unmake and remake social worlds (Ibid, pp. 293-295). Domestic violence and warfare can then form a single complex of violence, together waging what might be called "intimate war" (PAINE 2015). This link between gendered social worlds, violence and displacement becomes stronger when fragile states can no longer maintain their security or provide sufficient support for persecuted citizens, or if there are no institutions that could offer protection in the first place. At the time of this research, the fragile Iraqi state only enjoyed limited support from the population and did not protect citizens from arbitrary arrests, while corruption was rampant: there is a direct relationship between these failures to protect people from threats in their everyday life and their eventual displacement or decision to leave.

Another factor behind displacement is widespread fear. Much more than an individual response to danger, fear can penetrate social memory and become a chronic condition, writes Linda Green in reference to Guatemala: "Fear destabilizes social relations by driving a wedge of distrust within families, between neighbours, among friends. Fear divides communities through suspicion and apprehension not only of strangers but of each other" (Green 1994, p. 227). Especially in the face of fear and widespread suspicion, mutual trust would be an important resource. Yet such trust simultaneously erodes with escalating fear. One may speak of "economies of trust" in this sense, which are an essential aspect of social relations among refugees, especially because displacement so often uproots social order and creates a climate of suspicion (SCHIOCCHET 2014). 
The impact of fear and suspicion on Iraqi society becomes shockingly clear in the stories of those who sought refuge in Austria. The Kurdish decorator I3 had a brother who got into trouble with the Badr militia when he refused to comply with some of their orders. One day I3 drove into Baghdad's Adhamiya district, where he should have decorated a new building. Instead of meeting his client, however, "they" dragged him into a car and drove him somewhere where he was locked in for days, apparently solely for the purpose of putting further pressure on his brother. After about a week, his kidnappers threw him back onto the street in front of a grocery store. The shopkeeper gave him some water to drink. However: "He did not ask me a single question; not who these people were or why they did that to me. It seemed like he was almost used to it, as if they constantly dropped the bodies of kidnapped people in front of his shop," said I3, adding that people were simply too scared. Even if they shot someone in front of his eyes, he would not interfere. "Our situation in Iraq is special," he said, thereby offering an understatement for the carnage displaced Iraqis suffer. Could he not call the police to get help? "The police would only laugh at you," and although nobody helped him, if he was "in their place," he would not help others either. He continued: "The fear is too strong. Maybe the person I help is under observation and if I help him, I would take the side of the kidnapped and they kill me or kidnap me. Such thoughts go through your mind in such a situation." After "they" visited his brother once again and threatened to kill him, the decision to leave eventually became inevitable.

The 24 year-old Sunni Arab I4 was equally threatened, but said that "sometimes you don't even know who threatens you if you are threatened; you get a message demanding that you choose one side or another." It was a Shia militia that threatened him and the aunt he lived with in 2009, but this singular event was only the tipping point: "My whole life in Iraq was drowned in fear and sorrow. There is this permanent fear that accompanies you because you never know at which moment you might be killed." Militias also targeted him because he was an orphan, an easy recruit. To escape the pressures he fled to Syria before the civil war there, but when he returned to Iraq, fear dominated his life. "The situation in Iraq is so dangerous. If you go outside, what do you want to do there, or where can you even go? This is why I stayed home most of the time, silent and quiet."

The context of fear and mistrust can have a sectarian element if militants pressure those belonging to the "enemy group," and yet the impact of pervasive violence goes much deeper than that. Take the answer of the Kurdish Iraqi I3 to the question of how he coped with times of war in the past. When the United States invaded Iraq, he was only about 15 years old, but remembers a climate of constant fear and uncertainty. A year or so after the invasion, "murder and intrigues spread." His father worked as a taxi driver and after almost dying in a car accident, was briefly kidnapped and had his car stolen. According to I3, these "everyday" threats were soon accompanied by Islamist groups trying to enforce conservative clothing in public, and the trajectory of the ensuing violent conflict contributed to another "phase": "No Shiite dared to enter our Sunni quarter and the same the other way around. They murdered each other, and 
kidnappings and explosions were daily occurrences at that time." More than a mere episode in the recent history of Iraq, the culture of war and sectarian violence has shaped the lives of an entire generation: some participating, some escaping. He said:

"Today's generation does not have any moral standards. In today's Iraq, you are cultivated if you avoid Sunnis as a Shia Muslim. Is that cultivated? Some of us once were more than brothers, but after these feuds between Sunnites and Shiites, many friendships broke apart. No more phone calls, no more visits, nothing."

Although international law sometimes creates the impression that a pure form of the refugee exists, it is clear that most displaced persons experience a much more complicated combination of factors which lack recognition within the current regime of simplified and reductionist categories. "As soon as you start talking to refugees you realize there's always a mixture of motives, ” said GoodwIN-GILL of Oxford University in a 2012 analysis (IRIN 2012), adding: "The pure refugee does exist, but there are many others who face insecurity because of economic problems and persecution."

I17, a Kurdish man from Tikrit who later moved to Kirkuk, talked about how the impact of war and violence gradually made daily life impossible. He used to work for an Egyptian company based in Baiji, often welcoming visiting delegations and taking them across the border in and out of Erbil, Kurdish Iraq's capital. "With the rise of ISIS it became difficult for us. On the one hand, the bombings, on the other, ISIS demanding that youth fight for them," he said, adding that he tried to live with his family in Kirkuk, but one day the company he had worked for withdrew from Iraq. "So we sat there in Kirkuk, four young people without work, without anything." They sold their cars to get by, but one day, he decided to up sticks and moved to Europe, "now that everyone goes." It was better than sitting around doing nothing, "and the situation in Iraq gets worse every day, not better." Asked more directly about the main reasons for this decision to leave, he said:

"The situation gets worse every day, no salaries and no work. In Kurdistan or Kirkuk, the Turkmens say 'he is Kurdish' and if you are from the south, they say 'he is a Shiite', while the Shiites say, 'he is Sunni' (...) There are kidnappings, deaths, explosions every day. Iraq is devastated. There are no jobs and we, as university graduates, only sit at home and wait."

War and violence not only destroy the economy and its opportunities, but also damage the social fabric that supports people in distress. "Now you have conflicts between friends," said I17, adding: "For example, if someone reads on Facebook that ISIS killed a Shia, a Shia will be mad and spread that Sunnis are the problem. And then Sunni friends will argue with him on Facebook. In Kirkuk, we had a lot of problems between Kurds and Arabs." Rather than following sectarian interests and supporting Saudi Arabia or Iran, people in Iraq should think of their shared heritage, said I17, adding: "I am Iraqi and you are Iraqi, but nobody thinks like this any longer. Everybody 
thinks that Shiites support Shiites and Sunnites support Sunnites. They don't reflect that we are one country, that we are all brothers."

Political violence can follow a sectarian logic, but it also divides friends and enemies, sometimes along the lines of moral principles. The 50 year-old Yazidi woman I12 witnessed the gradual implosion of all aspects of her everyday life before she left Iraq. She had had her own business in the centre of Baghdad for over ten years. "I had a house. I had a car. My life situation was excellent," she said, adding: "But recently our life began to worsen." Militias in Baghdad threatened and persecuted her, and the arrival of ISIS only made things more difficult for the professional cosmetician. At the time when ISIS-followers issued direct threats against her because of the salon, she discovered that she had cancer and moved to Lebanon for medical treatment. Remembering the last years of her time in Iraq, she summarised the carnage:

"We didn't really live. We were like machines. We fought for our life every day, had to stand the worst surrounding us so that we can continue somehow. I went to work and something blew up close by, there were attacks and explosions. It means that I could have died every moment. (...) When I arrived at my cosmetic studio, I had to reckon that militias could attack and kill me any moment. At home I locked the door and prayed to the prophets of all religions that they protect me and help me to survive the next day. Psychologically, we reached the endpoint. We were already destroyed."

Just like this woman could no longer run her cosmetic salon, the 35 year-old Yazidi man I10 could no longer run his grocery store because it sold alcohol in the city of Hillah. Unsuccessful in finding another job, he had to continue his business until he received another, more serious threat during a "visit" and eventually decided to leave the country towards Austria, where he now has refugee status. "They said they will kill me unless I close down the shop," he said, adding: "Once you reach the point where you are threatened, that's it. You can no longer continue and have to flee."

The pervasive nature of violence, fear and danger emerging from these accounts often includes direct threats but has effects that go far beyond these. Economic and moral issues, such as a ban on alcohol or cosmetics, mix with sectarian divides and a culture of clientilism and corruption. Despite striking similarities across these cases, displacement emerges from this discussion as a many faceted process that can only be understood in the context of each individual case.

\section{Syria: political displacement and immobility in a protracted crises}

Although emerging with upheavals as recent as 2011, the Syrian crisis has entered the list of protracted conflicts. Due to its enduring character, such crises raise pressing 
questions in a world where the category of the "refugee" is inherently connected to temporariness and the option of returning home. The Syrian refugee crisis reached "catastrophic proportions," and the impact of multiple armed militias, factionalism, and sectarianism hints at an "unresolved future" (GoodwIN-GILL 2014, p. vii). At the time of writing, its protracted nature and the pervasive impact of war and violence have become a political issue of global scale, and so this Syrian crisis shows in an unusually blunt manner how the humanitarian impact of war and violence intersect with politics on different scales, from the local to the regional and global level. When a short-term humanitarian crisis turns into deadlocked political conflicts with pervasive violence, what becomes of questions about displacement's reasons and push-factors?

Many of the most visible Syrian refugees in the Jordanian Za'atari camp I visited in 2013 had been Syrian army defectors and rebel leaders before their displacement (Hackl 2013). Their exile might have been prompted by the immediacy of violence, but its continuation emerged above all as a deeply political issue. As S4, a 53 year-old Syrian woman from Dar'a put it when interviewed in Austria: "Ask any Syrian, the cradle of the revolution is Dar'a. We are optimistic; we feel that one day the revolution will succeed. (...) But it needs time. Now everything is out of control."

A possible end to the refugee crisis is framed as a matter of successful political struggle, raising questions about the category of the refugee and its narrow legal framework. Yet even in this most intense of contemporary armed conflicts, the decision to leave cannot be reduced to such political exile and direct violence alone. Asked about her reasons for leaving Syria, the 37 year-old Yezidi woman S9 listed two push-factors: "First, my husband was caught, they tortured him very much. The second reason is that there was no work in Syria." It is difficult to imagine that a daily routine of "work" still matters under the impact of violence and torture, but it does. Together with a number of other factors, the absence of work can make life unliveable. The 35 year-old Kurdish woman S11, from the multi-ethnic city of Al-Qamishli, touched on several aspects of an unsustainable life. Her husband is a musician and once the war began, he was no longer able to give concerts, one main reason having been the pressure of conflict and the divisions it causes: he had to officially align himself with the regime in order to continue his life on stage. At the same time, S11 no longer felt safe enough to send her son to kindergarten, "because it was too dangerous" after car bombings hit the neighbourhood, "and so we began to contemplate if it wouldn't be better for us to go elsewhere."

Similar to the experiences of Iraqi refugees, the displaced Syrians interviewed for this study often witnessed a rapid decline of mutual trust and the implosion of communal relations at the time of their departure. Here, too, relations between neighbours rapidly turned into relations of mutual suspicion and opposition.

The 38 year-old Muslim Arab woman S13 from al-Hasaka remembered that ethnic or religious identity mattered much less "before the war," especially with regard to her husband, who is Kurdish. Her husband worked as an engineer on water issues for the government, and he increasingly faced difficulties doing his job. "Usually, in al-Hasaka, 
you can call anybody 'my uncle', we had good relations in the city," said S13, adding that the war and pervasive violence changed this sense of togetherness completely. In a similar vein, the 34 year-old Kurdish man S14 from al-Malikiya in the same region, said that people of different ethnic and religious identity there lived together "like a family". Although in memory, such togetherness may well be beautified, S13 offered a similar description for his time at the University true for his time at the University of Tishreen in Latakia, where he studied:

"There was no difference between Kurds, Arabs or Christians. But since 2012, this and our lives changed. People began to ask: are you Muslim? If you are Muslim, they ask are you Shia or Sunni? If you are Christian, they ask if you are Chaldean, Armenian, Assyrian or Syrian Orthodox."

As different groups sided with different camps in the civil war, al-Qaida and affiliates such as al-Nusra added another element into the already dangerous mix. Fearing for their children's safety, S14 and other citizens began to organise classes at the church and he became one of the volunteering teachers. One day, a pupil he had helped with private lessons in the past approached him and said that they were "with al-Qaida" and that he heard people are planning to come for him because he was a Muslim teaching in a church. He would not believe it until the pupil's father called him. "I decided to leave my home country within 24 hours," he said. The space within which everyday life was possible had shrunk gradually under the impact of violence: dangerous streets created the need for the shielded space of the church, but political dynamics destroyed this space for him too, making it impossible to continue such risky life.

This case hints at another overlooked element behind displacement "decisions", which always include a forced aspect and one of decision-making: immobility and entrapment. Mobility is usually ascribed to the metaphorical figure of the "nomad" or the "migrant", while the "refugee" is characterised as immobile and regulated within tight regimes. What becomes clear in stories of displacement is that these two elements intersect, as entrapment can trigger forced mobility, which in turn leads to confinement. S18, a Sunni Arab from Damascus belonging to a family supporting the opposition, recalled the situation that made him leave the country:

"The circumstances were very, very difficult. (...) I was afraid to move in my area, [afraid] to go to any place because I might be arrested again (...). I passed through a period where I couldn't move (...) I was just sitting at home, afraid of being arrested."

The extent to which the potential of violence and death in everyday life and public space immobilises people seems essential for understanding their decisions to leave $-\mathrm{a}$ decision that comes to symbolise an empowering move in the face of confinement. Such confinement in the midst of war is what Philippe Van Leeuw masterfully expressed in his 2017-drama film Insyriated, which portrays a Syrian family stuck in one of the 
last inhabited apartments in a besieged building block. Such immobility within war is directly linked to the imminence of violence both as an actuality and a potentiality, and it makes work and public life unsustainable. In a similar vein S19 - from the same family as S18 - talked about walking an ever narrower and increasingly dangerous path before deciding to leave his home country, suggesting that being visible played a key role here. Working as a nurse "with the opposition" in "liberated areas" around Damascus, he was repeatedly interviewed on TV, until "problems happened with armed factions" who pressured him to stay away. Unable to evade such confrontation and persecuted for political reasons, leaving remained the only viable option.

These insights into processes of displacement from Syria underline the many ways in which violence and other push-factors intersect. As a set of interviews with displaced persons in the host country, the depth of the data is of course limited and lacks on-theground context. They nevertheless open up windows into important and often overlooked aspects of displacement. Moreover, as a deeply political and increasingly protracted crisis, the Syrian case also raises pressing questions about the current refugee regime and the dwindling space of refuge as a right. This is no less true for Afghanistan.

\section{Afghanistan: displaced women, "infidels" and forced returnees}

Although the Syrian refugee crisis dominated headlines throughout 2016, Afghanistan had close to three million externally displaced people around the same time. Similar to Iraqis who were able to seek refuge in neighbouring states in the past, the displaced from Afghanistan have lost their main destinations with serious crackdowns on Afghan refugees in both Pakistan and Iran. In the shadow of Syria and to some extent Iraq, Afghan asylum seekers are also faced with a lack of recognition as refugees in Europe; they are "perceived to be fleeing conditions less dire than those in Syria and Iraq" (Kugelmann 2016). Indeed, the EU drafted a plan in 2016 to deport 80,000 Afghan asylum seekers back to Afghanistan into supposedly conflict free areas. Among the first families who returned were some who had bombs blow up outside their homes soon after arriving, pushing them to embark on the dangerous journey towards Europe once again embarking on the dangerous journey towards Europe once again (SHARAN 2016). Despite the EU's forced return programme, there is no doubt that the situation in Afghanistan remains dire and often life-threatening. According to one 55 year-old Afghan man in Austria (A4), the reasons behind displacement are very diverse:

"I had a lot of problems in Afghanistan: religious conflicts, daily attacks, there was no school, no university, the people were completely absorbed with problems. (...). This is why so many Afghans leave their homelands and emigrate towards Europe on the most difficult paths, through Iran, over the mountains, across the sea where many drown. The people 
leave because they are unhappy. If this was a secure country with education and work opportunities and no attacks, they would not have left. But they have no choice."

These multiple perils of war and flight are often paired with additional pressures for Afghan women, who may have to carry the double burden of domestic and political violence. This becomes clear in interviews with several Afghan women in Austria who had been married to relatives or strangers under severe pressure. The story of the now 27 year-old A7 shows clearly how gender is linked to the impact of pervasive violence, as one form of violence is only made possible through the insecurity and vulnerability caused by the flight from another. Her father was killed for being Shia at the peak of Taliban rule, which is why her mother decided to flee to Iran once she and her siblings grew older. Hoping for a better life and initially invited by a friend of her father, they made their way towards Iran but were abandoned by the smugglers and consequently trapped midway, unable to return and unable to move forward. As a result of this dilemma, she was pressured to marry the son of a man who offered help and financed them for a while. To her mother, "he said if you cannot pay the money you can give me your daughter," recalled A7, adding that this husband's family treated her "like a slave" until she was able to convince him, for the sake of their two children, to flee towards Europe.

In a similar vein, the now 40 year-old A10 fled Afghanistan in order to escape forced marriage. Also here the death of her father put her into a vulnerable situation, exploited by her uncle, a Taliban affiliate, who stepped in as acting head of family. The uncle planned to marry her to a fellow Taliban, but as A10 put it, "I didn't want to marry this white-bearded man." Instead she managed to escape towards Europe by hurriedly getting married to the nephew of her father's sister, aided by the man's wealthy family. These examples underline the particular vulnerability women face in the context of political violence. That political power dynamics are linked to kinship relations also becomes clear in the case of the 34 year-old man A11, who said that he only found out a woman had already been promised to a Taliban after he got engaged to her. Fearing the worst after a series of threats, he decided to leave Afghanistan for Austria.

Violent conflict often involves a contest over moral and ideological standards, which is why violence quickly extends into the private realm and even into the most treasured ceremonial practices. When the brother of A15, a 20 year-old man from the Laghman province, got married, friends and villagers insisted on inviting musicians and singers. This was much to the dislike of the Taliban, who issued a letter in which they declared an Islamic state and denounced music and entertainment based on that authority. His brother remained stubborn and wanted to celebrate his day with music, which the party eventually did until about midnight, when they were attacked by gunmen. His brother was killed. A15 feared for his own life and decided to leave the country.

Another driver behind displacement prominent in the case of Afghan refugees in Austria appears to be association with Western organisations and foreign actors. In a highly politicised context such as Afghanistan, being identified with foreign actors can be 
dangerous. Indeed, the 23 year-old Afghan A2 worked as a security guard at the entrance to the building of a European development agency when he was approached by "antigovernment" groups, demanding from him to execute a terrorist attack on the office. "This is the reason why we were forced to leave our home country, because we didn't want to do what they demanded, " he said, echoing what happened to another Afghan man from the province of Nangarhar: A3 worked for the same foreign development agency when he received threats "not to work with the infidels. " In a similar vein, the 24 yearold political science graduate and translator A8 worked for the development division of the Afghan government, "going into provinces and evaluating projects." Many of these were UN projects, which was reason enough to get him into trouble with the Taliban. Also the 34 year-old A9, who has lived in Austria for about two years, remembers having been threatened back in Afghanistan because he worked for the Ministry of the Interior. These cases make clear the extent to which displacement is often a political matter, as individuals become associated unwillingly with one party or another and based on such association, forced to flee. Drawing together some of the insights gained from Afghan, Syrian and Iraqi refugees and asylum seekers, the following concluding section will revisit some core ideas surrounding displacement against the backdrop of the research insights presented.

\section{Conclusions}

The problem of protracted conflicts and the displacement they trigger is one that can be scrutinised from two perspectives. One is that of refugees' home countries, be it Iraq, Syria or Afghanistan. Here we have seen the many processes that push people to flee and seek refuge in Europe or elsewhere. As armed groups spread, regional and international actors interfere and dispersed power struggles erode the state and its ability to maintain order. In consequence, work, family and the social fabric become fraught with violence and a climate of suspicion and mistrust. The impact of these conflicts on displacement in desolate or fragile states is intensified by the pervasiveness, intensity, and protraction of violence. On the other hand, if viewed by receiving states in Europe and beyond, one must notice that "national security" considerations and popular opinion erode the moral legitimacy of the legal framework that underlies the global humanitarian refugee regime. Unsurprisingly, in the face of global scapegoating and tightening state criteria for granting meaningful status to displaced persons, the protracted conflicts in refugees' home countries are mirrored by an increasingly protracted refugee crisis (AKRAM and SYrIng 2014). The 'Conclusion on Protracted Refugee Situations' from a special UN General Assembly meeting in 2009 underlined "the plight of millions of refugees worldwide who continue to be trapped in 'protracted refugee situations' for five years or more after their initial displacement, without immediate prospects for implementation of 
durable solutions. "3 This only fuels the defensive stance of most receiving states, which emphasise the need to maintain security and cultural authenticity while popular opinion against "open borders" grows, indicating a gradual dissolution of the moral universe refugee law is built on. The unresolved refugee situations reveal in a particularly clear manner "the gaps between principle and practice, the limits of laws and rules, and the temptation for various actors to exploit those gaps" (Goodwin-GiLl 2014, p. ix).

Against this backdrop, what can one learn from the many intertwined layers of displacement explored throughout this analysis? The first insight is that the reasons for displacement and seeking refuge are rarely one-dimensional. The criteria outlined in the 1951 Convention, such as well-founded fear or persecution on grounds of ethnic or religious affiliation, for example, are still clearly evident in most of the discussed cases. The question remains whether such factors can be isolated, and whether there is not an urgent need to establish a legal framework that recognises the complicated context of these protracted crises and the pervasive violence that inhabits them. Economic and political reasons cannot be sufficiently isolated from other factors in many of the cases presented. In some instances, political violence makes work and public life impossible. In other cases, the nature of one's work triggers violence, and in yet other situations, one's profession is in demand by violent actors who put pressure on individuals to comply. Across most of the cases discussed, the distinction between voluntary and involuntary migration is blurred. This distinction has long been considered untenable (RICHMOND 1988), and yet it is equally clear that an element of force and violence forms part of all cases presented in this paper, although it is rarely the only push-factor.

An element of force also speaks through the entrapment and shrinking alternatives many displaced persons experience in the months prior to their departure. Whether it is a cosmetician, a grocer selling alcohol, a security guard or a journalist - no profession seems absolutely safe from interference by armed groups. The dilemma these people face is that on the one hand, complying with their terms - facilitating an attack, closing down one's shop, supporting their propaganda, or ceasing to work altogether - often means the loss of a profession and of a livelihood. On the other hand, not complying is equally unfeasible and often results in death threats and other violent pressures. It is no surprise that leaving the country towards a more promising and stable region of the world becomes an option, even if it involves selling one's house and leaving one's family behind.

Although sectarianism emerges as an insufficient explanation for the relation between violence and displacement in Iraq, Syria and Afghanistan, it remains a major driving force behind the pervasive culture of threats and fear that makes the life of many unsustainable in these countries. Also gender-specific violence emerges through political violence and displacement. The case of Afghanistan showed how women are not only subject to domestic violence and forced marriages, but also highly dependent

3 Conclusion on Protracted Refugee Situations No.109 (LXI) - 2009; Executive Committee 61st session, Extraordinary Meeting: 8 December 2009:

http://www.unhcr.org/excom/exconc/4b332bca9/conclusion-protracted-refugee-situations.html 
on the patronage and the support of others, some of whom might exploit the particular vulnerability of the displaced to exercise control. Such exploitation includes groups that seek to control the boundaries of moral believes and acceptable practice by violent means. Once identified as an agent of immorality, infidelity, or simply as someone unwilling to comply under the influence of force, people in Iraq, Syria and Afghanistan often have no other choice than to move to another city, change profession or to stay hidden at home. Such short-term measures would probably suffice in a conflict that lasts a few months, but due to the protracted nature of these crises, many reach the realisation that the only escape that leads to safety is that which leads into exile.

Long-term research on the ground will be necessary to better understand how the experience of displacement compares to its legal and political representation within the current international refugee and migration regimes. A study such as this one, which is primarily based on narratives and memories from refugees and asylum seekers outside of their home country, can only sketch the multi-dimensional push-factors that trigger displacement. Amidst quickly changing political contexts and eroding legal principles there is an urgent need to "bring refugee studies home" into the context in which displacement emerges, recurs and so often endures.

\section{Bibliography}

ABID L. (2015), Ein Land in Fragmenten: Ethnien, Kulturen, Religionen Im Irak. In: KRAITT T. (ED.), Irak, Ein Staat Zerfällt. Hintergründe, Analysen, Berichte, pp. 11-35. Wien, Promedia.

Akram S.M. and Syring T. (2014), Still Waiting for Tomorrow: The Law and Politics of Unresolved Refugee Crises. Newcastle upon Tyne, Cambridge Scholars Publishing.

Ali A.K. 82013), Displacement in a Fragile Iraq. Forced Migration Review 43 (May 2013), pp. 58-59.

Das V. (2008), Violence, Gender, and Subjectivity. Annual Review of Anthropology 37, pp. $283-$ 299.

Goodwin-Gill G.S. (2014), Foreword. In: Akram S.M. and Syring T. (eds.), Still Waiting for Tomorrow: The Law and Politics of Unresolved Refugee Crises, pp. vii-xii. Newcastle upon Tyne, Cambridge Scholars Publishing.

Green L. (1994), Fear as a Way of Life. Cultural Anthropology 9 (2), pp. 227-256. <doi:10.1525/ can.1994.9.2.02a00040>

HACKL A. (2013), Politics and Power in Jordan's Za'atari Refugee Camp. <http://www.irinnews. org/analysis/2013/11/01/politics-and-power-jordan's-zaatari-refugee-camp>

ICG (2016), Fight or Flight: The Desperate Plight of Iraq's 'Generation 2000' (Middle East Report No169)".

IOM (2016), Migration Flows from Iraq to Europe: Reasons Behind Migration. Baghdad. $<$ http:// iomiraq.net/article/0/iraqi-migration-europe-iom-report>

IRIN (2012), Has the Refugee Convention Outlived Its Usefulness?. <http://www.irinnews.org/ analysis/2012/03/26/has-refugee-convention-outlived-its-usefulness $>$ 
Kaldor M. (2012), New and Old Wars: Organized Violence in a Global Era. Cambridge, Polity.

Kugelmann M. (2016), The Other Major Refugee Crisis: 3 Million Afghans. $<$ http://blogs.wsj. com/washwire/2016/06/20/the-other-major-refugee-crisis-afghanistans-plight/>

Mahler S.J. and Pessar P.R. (2006), Gender Matters: Ethnographers Bring Gender from the Periphery toward the Core of Migration Studies. International Migration Review 40 (1), pp. 27-63. <doi:10.1111/j.1747-7379.2006.00002.x>

MalkKi L.H. (1995), Refugees and Exile: From 'Refugee Studies' to the National Order of Things. Annual Review of Anthropology 24 (1), pp. 493-523. < doi:10.1146/annurev. anthro.24.1.493>

Mokbel M. (2007), Refugees in Limbo: The Plight of Iraqis in Bordering States. JOUR. Middle East Report, no. 244. Middle East Research and Information Project, Inc. (MERIP), pp. 10-17. <doi:10.2307/25164797>

Moore H.L. (2004), Global Anxieties Concept-Metaphors and Pre-Theoretical Commitments in Anthropology. Anthropological Theory 4 (1), pp.71-88. $<$ doi:10.1177/1463499604040848>

Otterman M. and HiL R. (2010), Erasing Iraq: The Human Costs of Carnage. London, Pluto Press.

Paine R. (2015), Intimate War. Political Geography 44, pp. 64-73. <doi:10.1016/j.polgeo. 2014.09.011>

Peteet J. (2007), Unsettling the Categories of Displacement. JOUR. Middle East Report, no. 244. Middle East Research and Information Project, Inc. (MERIP), pp. 2-9. $<$ doi:10.2307/25164796>

Richmond A.H. (1988), Sociological Theories of International Migration: The Case of Refugees. Current Sociology 36 (2), pp. 7-25. < doi:10.1177/001139288036002004>

Rossier M.K. (2011), A Review of Practices and Expert Opinions: Linking Humanitarian Action and Peacebuilding. CCDP Working Paper.

Salazar, N.B. (2017), Key figures of mobility: an introduction. Social Anthropology 25 (1), pp. 5-12.

SAsson J. (2010), The Iraqi Refugees: The New Crisis in the Middle East. London and New York, I.B. Tauris.

Schiocchet L. (2014), Suspicion and the Economy of Trust among Palestinian Refugees in Lebanon. The Cambridge Journal of Anthropology 32 (2). Berghahn Journals, pp. 112-127. <doi:10.3167/ca.2014.320210>

Sharan T. (2016), Why Europe's Plan to Send Afghan Refugees Back Won't Work. https://www. crisisgroup.org/asia/south-asia/afghanistan/why-europes-plan-send-afghan-refugees-backwont-work.

UNHCR (2016a), Global Focus: Iraq. http://reporting.unhcr.org/node/2547.

UNHCR (2016b), Global Trends: Forced Displacement in 2015.

World BANK (2011), World Development Report 2011. WDI. <doi:10.1596/978-0-8213-8439-8>

Zolberg A.R., Suhrke A. and Aguayo S. (1989), Escape from Violence: Conflict and the Refugee Crisis in the Developing World. New York and Oxford, Oxford University Press. 
